\begin{tabular}{|c|c|c|}
\hline 超 硬 石 膏 (") & 有限円柱 & $\gamma=\ell=8.00$ \\
\hline Elit cement & "I & $r=\ell=7.50$ \\
\hline 水硬性セメント & $\prime \prime$ & $\begin{array}{l}\prime=7.00 \\
\prime=7.50\end{array}$ \\
\hline $\begin{array}{l}\text { 低溶ポーセレン } \\
\text { Glass }\end{array}$ & $\begin{array}{c}\text { 不定 形 } \\
\text { ” }\end{array}$ & \\
\hline 高 溶 & i & \\
\hline
\end{tabular}

\section{6. 人間雬及び歯科材料の熱的性質に関する実験的研}

\section{究, 特に人間歯について}

第 2 報 不定形試料に上る温度伝導率の比較測定法を 用いての人間歯の温度伝導率について

$$
\text { (九幽大.1補) 坪根 踝 二 }
$$

口腔内に装着された歯科材料は臨床的に変化に富九だ 環境に扮かれるものであるが，乙れらの熱的性質が生活 㐘に与える影響は歯科臨木にとって極めて重要なことで ある，このためには，先ず人間茵の歯牙個体の熱的性質 を知る事が第一であり，との目的のために多くの研究報 告があるが，いずれ屯組織別の性質であり，複雑な測定 によらねばならない。

演者は，これを組織別ではなく，歯牙個体としての熱 的性梊, 特に温度伝導率を極好簡単な装置と測定方法 によって，かつかなりの精度をるって測定しうる事を目 的として基濋実験を続け，乙の目的に必要な測定方法， 装置を考案し，人間歯について実験を行なった。今回は その測定結果を発表し，できるならば，抜幽後の歯牙個 体の経年による熱的性質の変化についても需及してみた い.その結果を要約すれば,

1.人間菌を組織別ではなく，歯牙全体としての熱的 性質，特に温度伝導率を測定しその值を明かにした。

2.上記の目的のため, 必要な測定装置及び測定方法 を考案した。

3. 測定精度は概ね士5\%以内にその誤差を収める事 ができると考える

\section{質 疑}

$$
\text { (籍 正) 横 田 }
$$

温度伝導率と熱伝導率との相異を教えてほしい。

\section{応 答}

$$
\text { (1 補) 坪 根 }
$$

熱伝導率と温度伝導率との間には大体次のような関係が あり，これによって判断さるれと考える。

\section{熱伝導率 : $\lambda$}

温度伝導率 : a

比重: $r$

\begin{tabular}{|l|l|l|l}
$4.80 \times 10^{-3}$ & & 2.006 & \\
$2.38 \times 10^{-3}$ & & 2.678 & \\
$2.84 \times 10^{-3}$ & & 2.191 & \\
& & 2.157 & \\
$5.96 \times 10^{-3}$ & & & \\
& 0.163 & & \\
$6.52 \times 10^{-3}$ & 0.188 & 2.34 & $2.87 \times 10^{-3}$
\end{tabular}

比 熱: c

$\lambda=\mathbf{a} \cdot \mathbf{c} \cdot \boldsymbol{\gamma}$

\section{7. 前歯に垂直力を与えたときの変位}

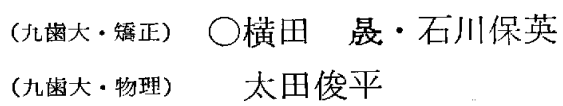

蒾周組織の生理的性状を知るために歯の圧入方向へ十 数 Kg の荷重を加えて歯の動きを計測した結果, 咬合力 の内いくらかは蒾膜の伸び，咬合力の大部分は王縮され た歯膜を介して根尖部の骨の抵抗により受けられている のではないかというデーターを得て昨年本学会で発表し た．今回は歯膜の引張りと圧縮のどちらが主体在成して いるかを知る必要上雬膜の伸びだけを検索するために引 張り方向の䨑の変位計測し, 压入の時の変形状態上比 較した．被験歯は20〜27才青年男子の中切崡30荬を用い た。

結果 : 圧入, 引張りのクリープ様挙動を $500 \mathrm{~g}, 1 \mathrm{~kg}$ について調べた結果，とあにその patternに差はなく， 力を加えた場合の变位に対しては時間的考慮を払わなく てよいと考えた. 圧入力最高 $28 \mathrm{~kg}$, 平均 $16 \mathrm{~kg}$, 引張り 力最高 $4.3 \mathrm{~kg}$, 平均 $2.3 \mathrm{~kg}$ 加えたところ，一般的弾性 率を $\mathrm{P}=\mathrm{KS}$ とすると（歯根膜厚，歯根面積を一定とし た場合), 压入では $30 \sim 60 \mu て ゙ \mathrm{~K} \fallingdotseq 7$, その後変曲点



引張りでは $30 \mu$ まで $\mathrm{K}=5 ， 60 \mu$ まで $\mathrm{K}=20$ ここで小 さな変曲点が現わ机る，それ以上は $\mathrm{K}=40 〜 50$ となるが 大局的には直線と見なして良い．

考察；以上を比較すると次のととがいえる。つまり初 期の変位は䨑周組織の伸びに 依存しており, 圧入力 1 kg前後ですでに歯周組織は根尖部で compact, 歯槽壁部 では伸びというちょうど中間的な状態であり，骨の変形 については今後追求するつありである.

\section{8. 影骨の歯牙許容量の成長による変化}

（九遏大・矮正）田島寛 妯 蒾牙の植立に必要な歯槽骨基底部の増令による成長堌 